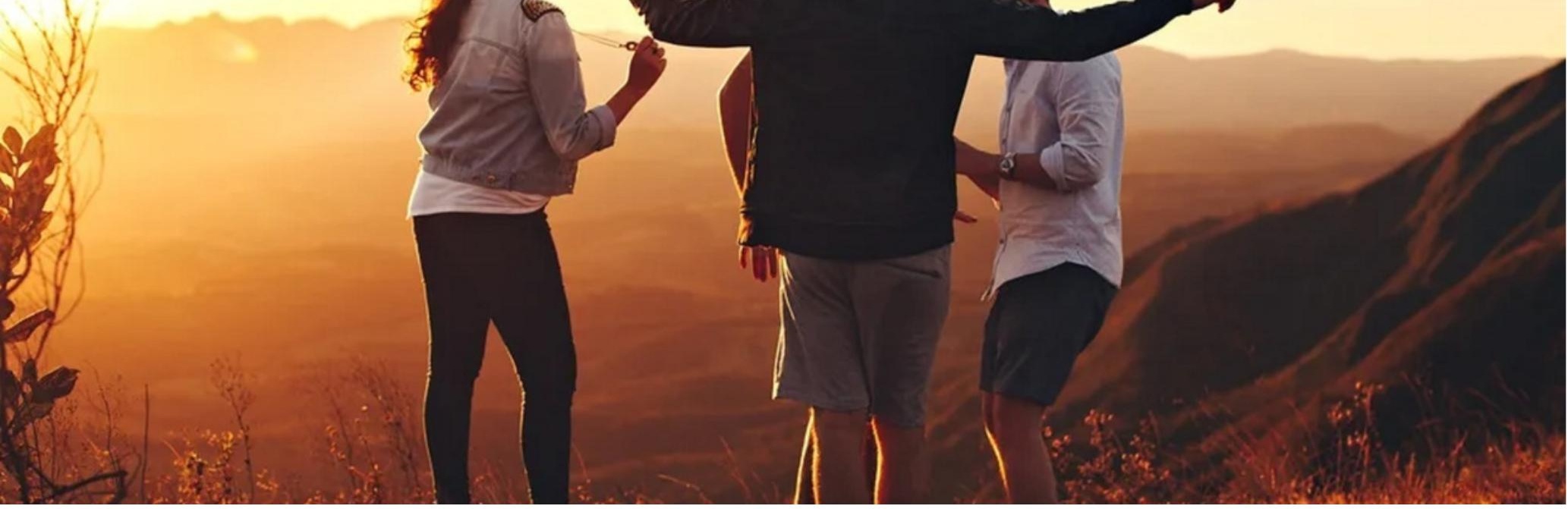

\title{
JOSHA SCHOLARSHIP FUND to support young students, artists, scientists from all around the world
}

\author{
Authors: Gerhard Steinmann, Silke Masullo \\ Submitted: $\quad$ 6. August 2020 \\ Published: $\quad$ 7. August 2020 \\ Volume: 7 \\ Issue: $\quad 4$ \\ Affiliation: International Academy of Sciences, Humanities, and Arts (IASHA \\ e.V.) \\ Languages: English \\ Keywords: Josha Fundraiser, knowledge for the world, Josha needs your \\ help. \\ Categories: $\quad$ News and Views \\ DOI: $\quad$ 10.17160/josha.7.4.703
}

\section{Abstract:}

JOSHA JOURNAL/ IASHA ACADEMY IASHA e.V. has provided scholarships to students since 2015. The requests for scholarships have significantly increased during the Corona Pandemic which is why we need your help to rapidly support students, artists and scientists who are in financial or economic distress. Scholarships are made available to local and international students to cover for their expenses. By reducing their financial barriers, we can help make education and career goals easier to obtain. In addition to the financial aid, our open-access internet journal JOSHA (www.josha-journal.org) lays out a forum where students, artists, and scientists can present their achievements to the public. There, you can value their presentations and follow-up on the impact of your funding. With your donation, you set a sign of philanthropy and help to continue our mission to support the future careers of many young and gifted neonle Thank vou for vour donationl httn//incha-iournal ora/en/donate

\section{JOSHA Jumnal stamene. Humanities and Arts}


JOSHA Journal/IASHA Academy.

IASHA e.V. has provided scholarships to students since 2015. The requests for scholarships have significantly increased during the Corona Pandemic which is why we need your help to rapidly support students, artists and scientists who are in financial or economic distress.

Scholarships are made available to local and international students to cover for their expenses. By reducing their financial barriers, we can support their education and career goals. In addition to the financial aid, our open-access internet journal JOSHA (www.josha-journal.org) lays out a forum where students, artists, and scientists can present their achievements to the public. There, you can value their presentations and follow-up on the impact of your funding.

With your donation, you set a sign of philanthropy and help to continue our mission to support the future careers of many young and gifted people.

Thank you for your donation! http://josha-journal.org/en/donate

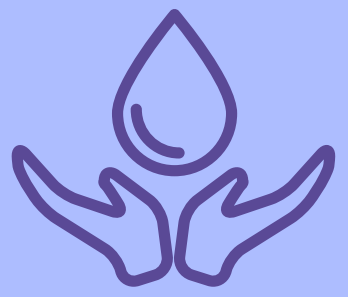

Donate here! 


\section{Voices of the JOSHA Scholarship Fund!}

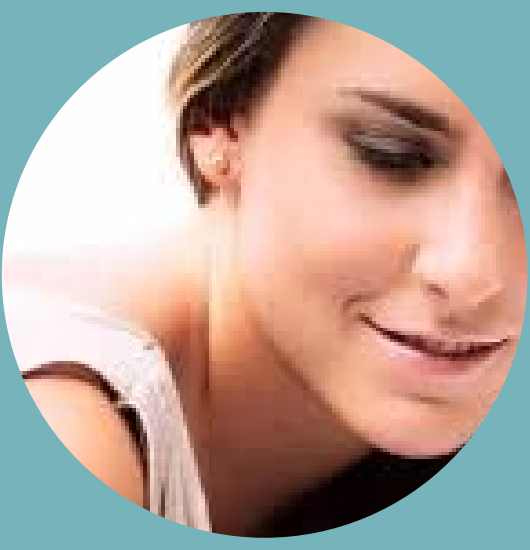

\section{Kim- Lillian Strebel}

This scholarship and support has played an absolutely crucial part in allowing me to get me to the place I am at right now. As a young artist at the time I was in the ensemble at Theater Freiburg where I had just began my professional career as an opera singer in the big wide world and was working so hard at

always improving my skills and putting myself out there in order to progress and get to the next level and sing at the best opera houses in the world. At the time I was not earning enough money to pay for all my singing lessons and coachings which for a young artist or even now still is so important to continue to have throughout your career. Also, I was having to travel to different opera houses in order to present myself to them by auditioning. This costs so much money and is not paid by the opera house. I was not able

to do this without the support of this foundation. I am so unbelievably grateful to have been picked to receive this help and

look forward to being able to give this opportunity to other young singers in the future. Especially now it is a very tough time for these young singers as work is so limited and there is pretty much no support for them. We need the young generation otherwise there will be no more opera.

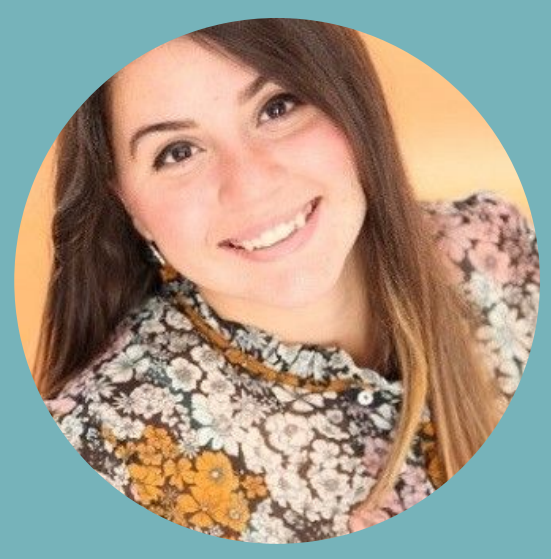

\section{Maria Sandoval}

JOSHA has been a wonderful experience throughout my student life in Germany and then in the beginning of my working life as Venezuelan living in Freiburg. If I had not listened to the recommendations of this super organization, I would not have dared to contact them and show them my desire to contribute to the world of knowledge through

my passion for the arts, music and

journalism. Thanks to them and their scholarship I had the opportunity to cross borders to interview important people about whom I later wrote articles. JOSHA has not only allowed me a financial support during my studies, but also the chance to practice writing as well as develop and discover my passion for media and design. Today I am at the beginning of my working life and I owe much of what I have learned so far to the opportunity that this organization gave me as a scholarship student!

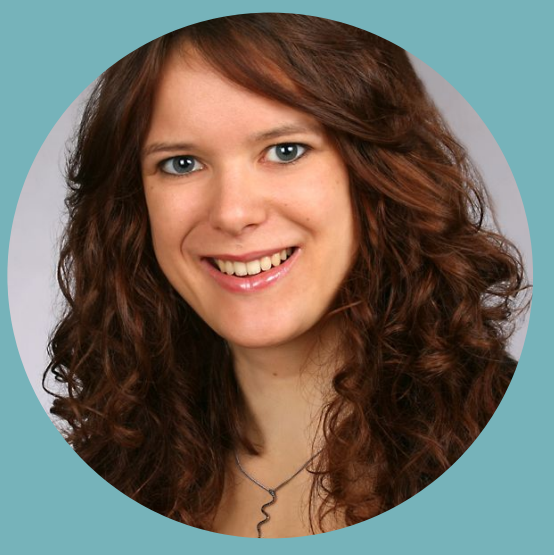

Marie Brendle

"I am so lucky to have got to know Prof. Dr. Roland Mertelsmann, a very inspiring person, during my medical studies, when I participated in an exchange program with Argentina that he created. Many years later, 2019, he supported me with the JOSHAscholarship "Pythagoras", that helped me in many ways. It is very difficult and thus so important nowadays, to have a multidisciplinary career. It takes longer to study and to find a job, and is a big financial investment, especially in music, because of the number of private classes you have to take to improve your skills. Multidisciplinarity

also leads me to participate in diverse projects in different countries like in Panama last december, with huge travel costs. JOSHA brought a multidisciplinary team together with this goal, and I feel so blessed to be part of it and see how much creative ideas are implemented. To me, music is a wonderful sensory and human experience that promotes empathy in a special way. My scientific education made it easier for me to understand the mathematical, logical issues

in music and broadened my horizons.

Physical activity leaves space to process and mature the spiritual activity.

Thank you for helping me and other young people making this possible!

\section{JOSHA Scholarship Fund 2020!}

Help us to make a difference!

\section{Donate here!}




\section{Learn more ahout the amazing young}

stud onts, artists and seientist who need innoling!

\section{Marta, Mika - Mezzosoprano}

What is your background? Give me a short biography of your singing?

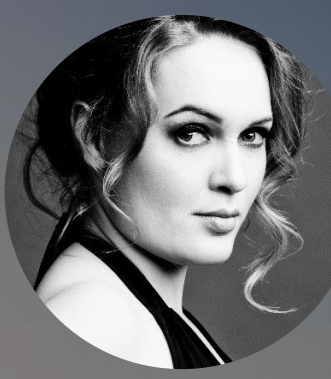

I was born in a family of musicians. My first introduction to music was learning the piano in Elementary School.

In 2004-2010 I continued my education in the Department of Rhythmic Art and Dance at a High School for Music. I then went on to do my Bachelor of Music in Opera at the Academy of Music in Cracow. In 2014-2016 I did my Master of Art in Opera- at the Fryderyk Chopin University of Music in Warsaw and participated in the Young Artist Program at the National Theatre in Warsaw.

2018-2020 I joined the Opera Studio at the Komische Oper Berlin.

Tell me what has it been like for you during corona as an opera singer and just as you ?

The Pandemic has been causing a great deal of financial problems for all artists, including myself. Flights and trains were cancelled during this time, so unfortunately, I couldn't get to any of my planned auditions which may have given me jobs for next season. Now I am left without a job for the next season which is very scary.

To make the best out of the situation, I managed to practice new repertoire at the Komische Oper, Berlin. What is your job situation at present?

My job situation at present is difficult. All the Opera Houses have already planned and cast the upcoming season. Sadly, my voice type is pretty common and very competitive and when there is a vacancy for a fixed ensemble member position it is hard to get it when you are still as young as I am and don't have as much experience as the others.

What's your plan to further your career?

Because there is no continuation of my job with the Komische Oper in Berlin, I have to try everything in order to find a new job, a new chapter in my career, new experiences on stage.

My plans for the next few months are to participate in as many auditions and competitions as possible. I would like to audition for the preliminary round of the Belvedere competition 2020 here in Berlin and attend the masterclasses for young opera singers (Exzellenz Labor Gesang 2020, Opera workshop with the French Agent René Massis and Hedwig Fassbender). I am also still waiting for the results of my participation in the Debut Concert 2020 Competition in Germany, so there are a lot of things to do in order for me to develop as an opera singer to reach my goals and dreams. As a young artist, I would love to have the opportunity to develop further my skills by joining an ensemble at an Opera House. This is the best way for a young artist to learn the skills by getting as much experience on stage with other singers as possible.

Tell me in one sentence how would the money from the foundation help you? The money from the foundation would help me to develop my skills and carcer goals and I would be able to pay for masterclasses and auditions.

\section{JOSHA Scholarship Fund 2020!} Help us to make a difference!

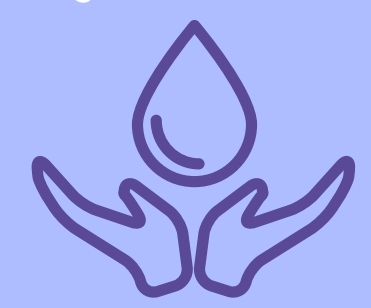




\section{Loarn more about the amazing young}

studonts, artists and seintsi who nobi fundingt

\section{Danae Kontora - Soprano}

What is your background? Give me a short biography of your singing?

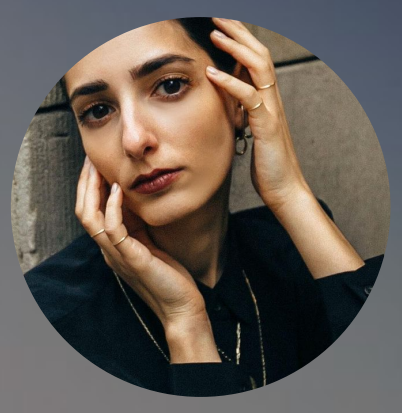

I was born and raised in Athens. I was introduced to Classical Music and Opera very early on in life since my mother used to listen to it from morning till night. From a very young age I was completely fascinated by the different sounds of the human voice, especially in the opera genre I suppose as the sound we hear is so different from the speaking voice. I first started studying music when I was 11 years old. I started with piano, took music theory lessons and joined the children's choir. I felt at home. I was lucky enough to participate in the productions of the Greek National Opera as a member of the children's choir. That gave me my first taste of being on the stage. After finishing High School, I started my studies in musicology in the University of Athens parallel to my opera and piano studies at the music school. A few years later I was accepted at the Hochschule für Musik und Theater, München where I finished my Diploma in Opern und Konzertgesang and obtained my Masters in Opera Performance.

Tell me what has it been like for you during corona as an opera singer and just as you?

During Corona I felt lucky at first since most of my contracts for 2019/20 were placed in the first half of the season. However, this changed and I started getting one cancellation after another for the many auditions that I had planned for this time. I have tried to stay as active and positive as possible and focused on self-education. I started learning Russian, read a lot of books, worked on my singing technique and even managed to become a decent cook.

What is your job situation at present?

At the moment I am unemployed. My 2020/21 season is unfortunately almost empty. Through auditions and concert loss I have no income and also not the possibility of future work. The fey things that are still planned for next season are a concert with the Tapiola Sinfonietta in Finland and some concerts with the Deutsche Kammerphilharmonie in Bremen and Hamburg. I tried to apply for a series of competitions to further my career and remain present but almost all competitions have been transferred by one year.

Tell me in one sentence how would the money from the foundation help you?

The money from the foundation would help me maintain myself in this very challenging time but also allow me to continue to develop myself as a singer and take voice lessons

www. danaekontora.com

JOSHA Scholarship Fund 2020!

Help us to make a difference!

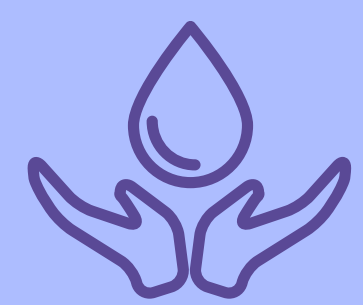

Donate here! 